\title{
Frequency and Type of Renal and Electrolyte Disorders in Fulminant Hepatic Failure
}

\author{
S. P. WILKINSON, L. M. BLENDIS, ROGER WILLIAMS
}

British Medical fournal, 1974, 1, 186-189

\section{Summary}

Of 48 patients with fulminant hepatic failure who progressed to grade III or IV encephalopathy 38 showed evidence of renal impairment. In 32 of these patients the underlying cause could be placed initially into one of three categories-prerenal uraemia (4 patients), acute tubular necrosis (16), and "functional renal failure" (12). The latter differed in several respects from that seen with liver failure secondary to cirrhosis. The frequency and type of renal impairment was the same in those patients in whom the fulminant hepatic failure had resulted from an overdose of paracetamol as in the other aetiological groups.

Abnormalities in plasma electrolytes were commonin particular hypernatraemia occurred in 11 patients from an osmotic diuresis precipitated by hypertonic dextrose or fructose given intravenously, and from the sodium in the fresh frozen plasma used to correct the coagulation disturbance when renal excretion of this ion was inappropriately low.

Liver Unit, King's College Hospital, London, SE5 8RX

S. P. WILKINSON, M.B., M.R.C.P., Research Fellow

ROGER WILLIAMS, M.D., F.R.C.P., Directer

Department of Gastroenterology, Central Middlesex Hospital, London N.W.10

L. M. BLENDS, M.D., M.R.C.P., Consultant Physician

\section{Introduction}

Two types of renal failure may occur in advanced cirrhosisnamely, acute tubular necrosis and "functional renal failure."1 The pathophysiology of the latter condition, which has attracted the most attention, ${ }^{2}$ appears to be reduced renal perfusion. ${ }^{3}$ In fulminant hepatic failure renal impairment is usually considered to be an important part of the clinical syndrome, ${ }^{4}{ }^{5}$ but little information is available on either its frequency or the type of renal impairment that occurs. Hecker and Sherlock ${ }^{6}$ described one patient with fulminant hepatic failure who, in retrospect, had the features of functional renal failure, and Ritt et al. ${ }^{7}$ found impairment of renal function in 13 out of 31 patients with acute hepatic necrosis but gave no information about its type.

In this paper we describe an analysis of the changes in renal function and plasma electrolytes seen in $\mathbf{4 8}$ patients with fulminant hepatic failure.

\section{Patients and Methods}

The patients were seen during the period April 1970 to September 1972, and all eventually progressed to grade III or IV hepatic encephalopathy (Trey et al. ${ }^{8}$ ). In 18 of the patients the cause was presumed to be infectious hepatitis; 8 had serum hepatitis with Australia antigen present in the serum; 15 had taken an overdose of paracetamol; 5 had had recent and multiple exposures to halothane; and in 2 the illness was attributed to a hypersensitivity reaction after administration of monoamine oxidase inhibitors. Patients with a known history of renal disease were excluded from the analysis.

\section{CLASSIFICATION OF CASES}

Patients in whom the plasma urea or plasma creatinine rose to 
levels greater than $45 \mathrm{mg} / 100 \mathrm{ml}$ or $1.8 \mathrm{mg} / 100 \mathrm{ml}$ respectively were separated into the following three groups.

Prerenal Uraemia.-The uraemia could be explained on the basis of dehydration or absorption of nitrogenous compounds from the gut after a gastrointestinal bleed.

Functional Renal Failure.-This term was used, as suggested by Vesin, ${ }^{\circ}$ to describe an otherwise unexplained renal impairment in the presence of a low urine sodium concentration (in the present series less than $18 \mathrm{mEq} / \mathrm{l}$.) and a normal urinary sediment. In all cases except those in which acute tubular necrosis also developed later the kidney was found to be normal at necropsy.

Acute Tubular Necrosis. - This diagnosis was based on the discovery of numerous granular and cellular casts in the urine and on the necropsy findings. A urine sodium concentration of over $20 \mathrm{mEq} / \mathrm{l}$. together with a urine:plasma urea ratio of less than 10 was considered additional evidence. Information on urine osmolality and specific gravity was not always available.

\section{Results}

High plasma urea or creatinine concentration were found in all except 10 patients, the latter group including the only six survivors in the series. In six of the 38 patients with possible renal impairment there were insufficient data to determine the most likely cause. In the remaining 32 patients the lesion initially appeared as prerenal uraemia (4 cases), functional renal failure (12 cases), and acute tubular necrosis (16 cases). Subsequently one of the patients with prerenal uraemia and four of those with functional renal failure developed acute tubular necrosis, so that ultimately there were 21 patients with this renal lesion.

Prerenal uraemia had first appeared in three of the four patients after dehydration and in each instance the blood urea fell with rehydration. In the fourth patient the raised blood urea was thought to be entirely due to absorption of an increased load of nitrogenous compounds from the bowel after a gastrointestinal bleed.

\section{FUNCTIONAL RENAL FAILURE}

Nine of the 12 patients fulfilled all the criteria for this diagnosis (table I, cases 1-9). The urine-plasma urea ratio was always less than 10 and in this respect indistinguishable from acute tubular necrosis, but the urine sodium concentration, urine sediment, and subsequent necropsy findings clearly distinguished these two types of renal impairment. Daily urine volumes varied from 50 to $1,000 \mathrm{ml}$. The other three patients (table I, cases 10-12) had all the features of functional renal failure except that the urine sodium concentrations were greater than $18 \mathrm{mEq} / 1$. At the time of urine collections, however, these patients had been receiving either intravenous frusemide $(250-1,000 \mathrm{mg})$ or intravenous mannitol $(15-40 \mathrm{~g})$ or both with apparently good responses (urine volumes increasing to between 750 and 1,700 $\mathrm{ml}$ daily), which may explain the higher urine sodium concentrations.

In eight of the 12 patients functional renal failure was already present on admission. At that time five patients were considered to have grade I, one grade II, and two grade III encephalopathy. In the others the first signs of functional renal failure were detected during the first three days after admission, two of them having grade II and two grade III encephalopathy at the time. The functional renal failure could not be related to the aetiology of liver necrosis, the treatment given-for example, heparin, fresh frozen plasma, or corticosteroids - or the liver funotion tests (bilirubin, plasma albumin, or prolongation of prothrombin time). Its course was invariably progressive regardless of clinical hepatic state. Treatment with diuretics appeared ineffective even in cases 10-12, since despite the increasing urine flow the plasma urea and creatinine concentrations continued to rise. In the other nine cases no significant diuresis resulted from treatment with frusemide and mannitol. Three patients in whom the plasma urea concentration rose to greater than $200 \mathrm{mg} / 100 \mathrm{ml}$ were treated by dialysis but without effect on their clinical condition.

Though a low urine sodium concentration is a feature of functional renal failure plasma sodium concentrations varied between $112 \mathrm{mEq}$ and $158 \mathrm{mEq} / 1$. (table $\mathrm{I}$, cases 11 and 7). No relation between plasma sodium and urine sodium concentrations could be detected; similarly there was no relation between urinary sodium excretion and sodium intake. Furthermore, not all patients with low urine sodium concentrations showed other evidence of renal impairment. Thus of the 48 patients 10 had 24-hour urine sodium excretions of less than $10 \mathrm{mEq} / \mathrm{l}$. when they were not oliguric, and four of these had normal plasma urea and creatinine concentrations.

\section{ACUTE TUBULAR NECROSIS}

In 18 of the 21 cases the first signs of acute tubular necrosis appeared after a hypotensive episode due to a gastrointestinal bleed. In 12 patients the lesion developed as a preterminal event in the last 24 hours of life. The biochemical findings in the nonterminal cases are given in table II. The renal failure was oliguric (urine volume less than $100 \mathrm{ml}$ in six hours) in 18 of the cases, the exceptions having daily urine volumes of greater than $900 \mathrm{ml}$. Mannitol and frusemide were given to these patients in doses similar to those given to patients with functional renal failure, but in none was an appreciable diuresis produced.

As with functional renal failure the development of acute tubular necrosis could not be related to the aetiology, changes in liver function, or treatment of the hepatic failure. Examination of the kidneys at necropsy in the patients who had taken an overdose of paracetamol showed no evidence of papillary necrosis.

TABLE I-Findings in 12 Patients with Functional Renal Failure. Values refer to Single and Representative Day. Cases 10, 11, and 12 were receiving Diuretic at Time of Urine Collection

\begin{tabular}{|c|c|c|c|c|c|c|c|c|c|}
\hline \multirow{2}{*}{$\begin{array}{l}\text { Case } \\
\text { No. }\end{array}$} & \multirow{2}{*}{$\begin{array}{c}\text { Aetiology of } \\
\text { Hepatic Failure }\end{array}$} & \multicolumn{3}{|c|}{ Plasma } & \multicolumn{4}{|c|}{ Urine } & \multirow{2}{*}{$\begin{array}{c}\text { Urine: } \\
\text { Plasma } \\
\text { Urea } \\
\text { Ratio }\end{array}$} \\
\hline & & $\begin{array}{c}\text { Urea } \\
(\mathrm{mg} / 100 \mathrm{ml})\end{array}$ & $\begin{array}{l}\text { Creatinine } \\
(\mathrm{mg} / 100 \mathrm{ml})\end{array}$ & $\begin{array}{l}\text { Sodium } \\
(\mathrm{mEq} / 1 .)\end{array}$ & $\begin{array}{l}\text { Sodium } \\
(\mathrm{mEq} / 1 .)\end{array}$ & $\begin{array}{c}\text { Potassium } \\
(\mathrm{mEq} / \mathrm{l} .)\end{array}$ & $\begin{array}{c}\text { Urea } \\
(\mathrm{mg} / 100 \mathrm{ml})\end{array}$ & $\begin{array}{c}\text { 24-hour } \\
\text { volume (ml) }\end{array}$ & \\
\hline $\begin{array}{l}1 \\
2 \\
3 \\
4 \\
5 \\
6 \\
7 \\
8 \\
9\end{array}$ & $\begin{array}{l}\text { Hepatitis } \\
\text { ” } \\
\text { ” } \\
\text { Paracetamol } \\
\text { ” } \\
\begin{array}{c}\text { Monoamine oxidase } \\
\text { inhibitor }\end{array}\end{array}$ & $\begin{array}{r}43 \\
68 \\
83 \\
283 \\
45 \\
38 \\
83 \\
63 \\
23\end{array}$ & $\begin{array}{r}1.9 \\
4.0 \\
10.9 \\
2.6 \\
4.8 \\
\frac{1.7}{1.7} \\
3.4\end{array}$ & $\begin{array}{l}122 \\
118 \\
118 \\
138 \\
128 \\
115 \\
158 \\
150 \\
140\end{array}$ & $\begin{array}{c}7 \\
13 \\
4 \cdot 7 \\
17 \\
9 \\
11 \\
4 \\
8 \\
6\end{array}$ & $\begin{array}{l}61 \\
16 \\
26 \\
31 \\
23 \\
31 \cdot 5 \\
34 \cdot 5 \\
24 \\
10\end{array}$ & $\begin{array}{l}170 \\
200 \\
330 \\
300 \\
300 \\
180 \\
380 \\
250 \\
140\end{array}$ & $\begin{array}{r}300 \\
500 \\
150 \\
60 \\
630 \\
480 \\
910 \\
1,000 \\
\quad 50\end{array}$ & $\begin{array}{l}4 \cdot 0 \\
2 \cdot 9 \\
4 \cdot 0 \\
1 \cdot 1 \\
6 \cdot 7 \\
4 \cdot 7 \\
4 \cdot 6 \\
4 \cdot 0 \\
6 \cdot 1\end{array}$ \\
\hline $\begin{array}{l}10 \\
11 \\
12\end{array}$ & $\begin{array}{l}\text { Hepatitis } \\
\text { Paräcetamol }\end{array}$ & $\begin{array}{r}350 \\
216 \\
80\end{array}$ & $\begin{array}{l}\overline{3 \cdot 7} \\
2 \cdot 0\end{array}$ & $\begin{array}{l}113 \\
112 \\
138\end{array}$ & $\begin{array}{l}38 \\
20 \\
49\end{array}$ & $\begin{array}{l}36 \\
40 \\
82\end{array}$ & $\begin{array}{l}\quad 550 \\
\quad 650 \\
\text { (Creatinine } \\
\text { 37 mg/100 } \\
\mathrm{ml} \text { ) }\end{array}$ & $\begin{array}{r}750 \\
1,100 \\
1,700\end{array}$ & $\begin{array}{l}\quad 1.6 \\
\quad 3.0 \\
\text { (Urine: } \\
\text { plasma } \\
\text { creatinine } \\
\text { ratio } 18.5 \text { ) }\end{array}$ \\
\hline
\end{tabular}


TABLE II-Findings in Nine Patients with Non-terminal Acute Tubular Necrosis

\begin{tabular}{|c|c|c|c|c|c|c|c|c|c|}
\hline \multirow{2}{*}{$\begin{array}{l}\text { Case } \\
\text { No. }\end{array}$} & \multirow{2}{*}{$\begin{array}{c}\text { Aetiology of } \\
\text { Hepatic Failure }\end{array}$} & \multicolumn{3}{|c|}{ Plasma } & \multicolumn{4}{|c|}{ Urine } & \multirow{2}{*}{$\begin{array}{c}\text { Urine: } \\
\text { Plasma } \\
\text { Urea } \\
\text { Ratio }\end{array}$} \\
\hline & & $\begin{array}{c}\text { Urea } \\
(\mathrm{mg} / 100 \mathrm{ml})\end{array}$ & $\begin{array}{c}\text { Creatinine } \\
(\mathrm{mg} / 100 \mathrm{ml})\end{array}$ & $\underset{(\mathrm{mEq} / \mathrm{l} .)}{\text { Sodium }}$ & $\begin{array}{l}\text { Sodium } \\
\text { (mEq/1.) }\end{array}$ & $\begin{array}{c}\text { Potassium } \\
(\mathrm{mEq} / \mathrm{l} .)\end{array}$ & $\begin{array}{c}\text { Urea } \\
(\mathrm{mg} / 100 \mathrm{ml})\end{array}$ & $\begin{array}{c}\text { 24-hour } \\
\text { Volume (ml) }\end{array}$ & \\
\hline $\begin{array}{r}2 \\
3 \\
13 \\
14 \\
15 \\
16 \\
17 \\
18 \\
19\end{array}$ & $\begin{array}{c}\text { Hepatitis } \\
\text { ", } \\
\text { ", } \\
\text { ", } \\
\text { Paracetamol } \\
\text { Halothane } \\
\text {," }\end{array}$ & $\begin{array}{r}73 \\
165 \\
160 \\
147 \\
83 \\
260 \\
50 \\
80 \\
85\end{array}$ & $\begin{array}{l}\frac{\overline{10.5}}{4.5} \\
= \\
\bar{z} \\
1.8\end{array}$ & $\begin{array}{l}120 \\
116 \\
140 \\
131 \\
120 \\
124 \\
140 \\
121 \\
141\end{array}$ & $\begin{array}{l}22 \\
21 \\
20 \\
27 \\
22 \cdot 5 \\
32 \\
\frac{77}{30}\end{array}$ & $\begin{array}{l}14 \\
20 \\
56 \\
69 \\
69 \cdot 5 \\
65 \\
16 \\
34\end{array}$ & $\begin{array}{l}150 \\
300 \\
890 \\
280 \\
560 \\
520 \\
100 \\
240\end{array}$ & $\begin{array}{r}300 \\
100 \\
920 \\
100 \\
400 \\
1,120 \\
2,000 \\
300 \\
200\end{array}$ & $\begin{array}{l}2 \\
1 \cdot 8 \\
5 \cdot 6 \\
1.9 \\
6 \cdot 7 \\
2 \\
2 \\
\frac{2}{2 \cdot 8}\end{array}$ \\
\hline
\end{tabular}

TABLE III-Relevant Data on Seven Patients with Hypernatraemia. (Values for Sodium Excretion, Urine Volume, and Fluid Balance are Mean for Day preceding and Days during Period of Hypernatraemia. Blood Glucose and Plasma Sodium Values are highest observed at this Time)

\begin{tabular}{|c|c|c|c|c|c|c|c|c|}
\hline \multirow{2}{*}{$\begin{array}{l}\text { Case } \\
\text { No. }\end{array}$} & \multirow[b]{2}{*}{ Intravenous Fluids } & \multirow{2}{*}{$\begin{array}{c}\text { Blood } \\
\text { Glucose } \\
(\mathrm{mg} / 100 \mathrm{ml})\end{array}$} & \multirow{2}{*}{$\begin{array}{l}\text { Plasma } \\
\text { Sodium } \\
(\mathrm{mEq} / \mathrm{l} .)\end{array}$} & \multicolumn{2}{|c|}{ Urine } & \multicolumn{3}{|c|}{ Fluid Balance $(1 . / 24 \mathrm{hr})$} \\
\hline & & & & $\underset{\text { (mEq/24 hr) }}{\text { Sodium }}$ & $\begin{array}{l}\text { Volume } \\
\text { (1./24 hr) }\end{array}$ & Intake & Output* & $\begin{array}{c}\text { Net } \\
\text { Balance }\end{array}$ \\
\hline $\begin{array}{l}1 \\
2 \\
3 \\
4 \\
5 \\
6 \\
7\end{array}$ & $\begin{array}{l}\text { Fresh frozen plasma, } 10 \% \text { dextrose } \\
\text { Fresh frozen plasma, } 5 \% \text { and } 20 \% \text { dextrose } \\
\text { Fresh frozen plasma, } 50 \% \text { dextrose } \\
10 \% \text { Fructose } \\
\text { Fresh frozen plasma, } 10 \% \text { dextrose } \\
\text { Fresh frozen plasma, } 10 \% \text { dextrose } \\
\text { Fresh frozen plasma, } 5 \%, 25 \% \text {, and } 50 \% \text { dextrose }\end{array}$ & $\begin{array}{l}374 \\
300 \\
850 \\
330 \\
444 \\
329 \\
805\end{array}$ & $\begin{array}{r}179 \\
161 \\
165 \\
>160 \\
158 \\
150 \\
163\end{array}$ & $\begin{array}{r}17 \\
146 \\
62 \\
18 \\
21 \\
\end{array}$ & $\begin{array}{l}4 \cdot 5 \\
4 \cdot 0 \\
3.5 \\
2 \cdot 3 \\
2.5 \\
3.5 \\
4 \cdot 5\end{array}$ & $\begin{array}{l}4.5 \\
3.5 \\
3.0 \\
3.8 \\
3.8 \\
3.0 \\
5.0\end{array}$ & $\begin{array}{l}5 \cdot 5 \\
5 \cdot 0 \\
4 \cdot 5 \\
4 \cdot 3 \\
3 \cdot 8 \\
4 \cdot 8 \\
6 \cdot 0\end{array}$ & $\begin{array}{l}-1 \\
-1.5 \\
-1.5 \\
-0.5 \\
0 \\
-1.8 \\
-1\end{array}$ \\
\hline
\end{tabular}

*Fluid output includes urine, gastric aspirate, and insensible loss.

N.B. Case numbers do urine, gastric aspirate, and insensible loss.

\section{ABNORMALITIES IN PLASMA ELECTROLYTES AND FLUID BALANCE}

An unexpected finding was hypernatraemia in 11 patients, all of whom died. In seven of these complete fluid-balance charts were available for analysis (table III). In six patients this showed the presence of a persistently negative fluid balance associated in each instance with an osmotic duiresis resulting from the administration of intravenous hypertonic dextrose or fructose. Urine volumes increased out of proportion to the relatively little sodium excreted. There was always an accompanying rise in blood urea, though this did not necessarily exceed the upper limit of normal. The development of hypernatraemia in one patient is shown in the fig. Analysis of the fluid-balance charts in

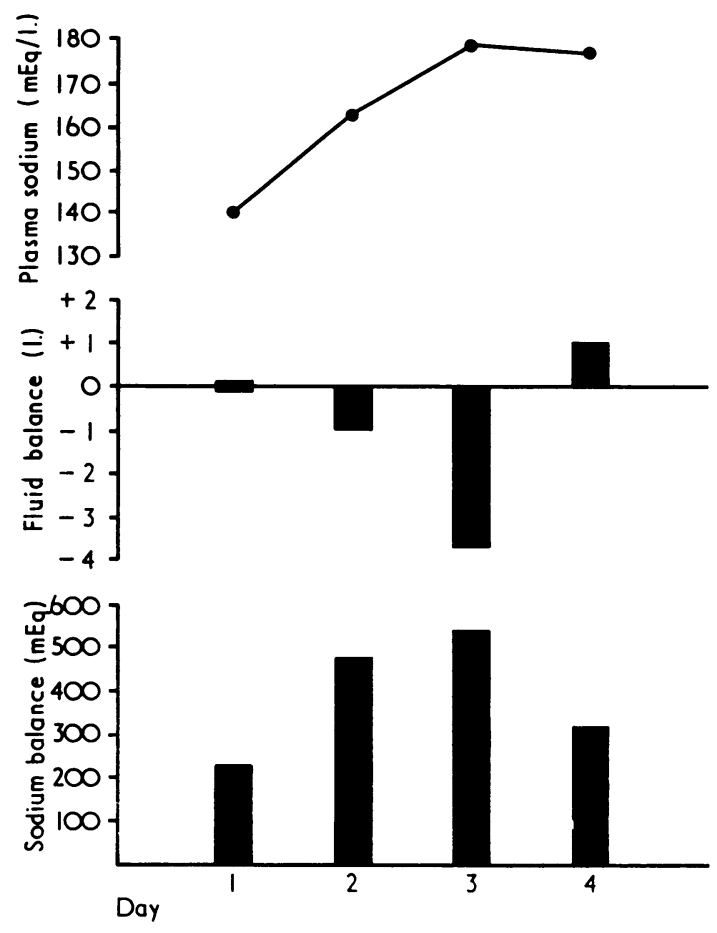

Sodium and fluid balance in a patient with hypernatraemia
15 patients without hypernatraemia showed that none had a negative daily fluid balance of greater than 0.51 . for more than one day.

Six of these seven patients had also received at least $300 \mathrm{mEq}$ of sodium each day as fresh frozen plasma to treat the coagulation disturbance. Similar amounts of plasma had been given to another 28 patients, who had not developed hypernatraemia, but none of those patients had evidence of a persistently negative fluid balance.

The other changes in the plasma electrolytes included hyponatraemia (plasma sodium concentration less than $130 \mathrm{mEq} / \mathrm{l}$.) in 23 patients, which usually developed late in the course of the illness. In contrast hypokalaemia (plasma potassium concentration less than $3.8 \mathrm{mEq} / 1$.), found in 23 patients, was often present on admission. In five patients there was subsequently a rise in plasma potassium concentration to over $5.2 \mathrm{mEq} / \mathrm{l}$. as renal failure developed.

\section{Discussion}

The functional renal failure seen in these patients with fulminant hepatic failure was somewhat similar to that found in advanced cirrhosis-for instance, the urine sediment and necropsy findings were normal. There were, however, differences. The mean urine:plasma urea ratio in the cirrhotic patients with functional renal failure reported on by Baldus et al. ${ }^{2}$ was 25 , whereas it was always less than 10 and usually less than 5 in our patients. The urine:plasma urea ratio may be a poor guide to renal function at low urine flow rates, ${ }^{10}$ but seven of our 12 patients had a daily urine volume of $500 \mathrm{ml}$ or more (table I). Possibly the changes in renal haemodynamics are different. If there was a relatively higher medullary blood flow in fulminant hepatic failure this would be expected to "wash out" the medullary urea, thus accounting for the comparatively low urine urea, since equilibration occurs between urea in the medullary interstitium and collecting ducts. The plasma sodium and urinary sodium concentrations were often higher in our patients than in those suffering from cirrhosis with functional renal failure. This may be because they were receiving large quantities of sodium intravenously, as fresh frozen plasma, whereas strict sodium restriction is usually employed in patients with advanced cirrhosis. 
The lack of correlation between renal function and the results of liver function tests in the present cases was similar to that found in cirrhosis. ${ }^{11} \mathrm{~A}$ frequently quoted theory to explain functional renal failure in cirrhosis is that portal hypertension causes a pooling of blood in the splanchnic circulation with a resulting decrease in "effective" systemic (and therefore renal) blood volume. An increase in portal pressure may occur in acute hepatitis. ${ }^{12}$ Though this was not measured in our patients 10 of the 12 had ascites and one had oesophageal varices, which indicate portal hypertension.

The same types of renal lesion were encountered regardless of the aetiology of hepatic failure. Though paracetamol overdosage has been said to be a specific cause of renal damage ${ }^{13}$ this has not been our experience. Development of renal failure in fulminant hepatic failure clearly indicates a poor prognosis. Nevertheless, we have recently seen five patients with acute tubular necrosis in association with acute hepatic damage (three due to serum hepatitis, and two due to paracetamol overdosage) in whom encephalopathy did not occur and whose kidney function finally recovered.

When renal impairment does develop in these patients it is likely to have certain adverse consequences. Uraemia may contri bute towards the coma, bleeding diathesis, high risk of infection and raised blood levels of ammonia. ${ }^{14}$ Bilirubin is potentially toxic to cellular metabolism, ${ }^{15}$ and bile salts are toxic to various tissues including liver, ${ }^{16}$ kidney, ${ }^{17}$ and brain. ${ }^{18}$ These substances probably attain higher blood levels where there is renal impairment. ${ }^{19} 20$

Our finding of hypernatraemia in several patients was of particular interest. In most instances the mechanism appeared to be dehydration secondary to an osmotic diuresis which had been precipitated by the intravenous administration of hypertonic dextrose of fructose. Hypernatraemia resulting from an osmotic diuresis has also been described in cirrhosis. ${ }^{21}$ An additional factor may have been the intravenous administration of large quantities of sodium when renal excretion was inappropriately low. Another possible cause of excess renal water loss in fulminant hepatic failure is the development of a pituitary diabetes-insipidus-like syndrome. ${ }^{22}$ Hypernatraemia may itself cause coma, ${ }^{23}$ and hypertonic dextrose solutions should therefore be given to these patients only with considerable caution.
No rational suggestions can be made for preventing or reversing functional renal failure until the pathophysiology is better understood. Mannitol and frusemide are of no real value, and this is also the case in cirrhosis. ${ }^{2}$ Indeed, most workers agree that diuretics may be positively harmful in these cases. ${ }^{24}$

We are grateful to Dr. Victor Parsons and Dr. Vicente Arroyo for their critical evaluation, and to the Medical Research Council for their support.

\section{References}

${ }^{1}$ Shear, L., Kleinerman, J., and Gabuzda, G. J., American fournal of

Medicine, 1965, 39, 184.
2 Baldus, W. P., Feichter, R. N., Summerskill, W. H., Hunt, J. C., and Wakim, K. G., Annals of Internal Medicine, 1964, 60, 366.

3 Epstein, M., et al., American fournal of Medicine, 1970, 49, 175.

Trey, C., and Davidson, C. S., In Progress in Liver Disease, ed. H. Popper and F. Schaffner, vol. 3, p. 282. New York, Grune and Stratton, 1970.

${ }_{5}^{5}$ Williams, R., British Medical Bull tin, 1972, 28, 114.

6 Hecker, R., and Sherlock, S., Lancet, 1956, 2, 1121 .

7 Ritt, D. J., et al., Medicine, 1969, 48, 151.

8 Trey, C.., Burns, D. G., and Saunders, S. J., New England fournal of Medicine (Baltimore), 1966, 274, 473.

${ }^{9}$ Vesin, P., in Aktuelle Probleme der Hepatologio: Ultrastruktur Steroidstoffwechsel Durchblutung Leber und Niere, ed. G. A. Martini and S. toff wechsel Durchblutung Leber und Niere,
Sherlock, p. 98. Stuttgart, Thieme, 1970.

10 Merrill, J. P., in Diseases of the Kidney, ed. M. Strauss and L. Welt, 2nd Merrill, J. P., in Diseases of the Kidney, ed.

11 edn., p. 637. Boston, Little, Brown, 1971 . Medicine, i, $964,60,353$.

12 Haerter, W., and Palmer, E. D., American fournal of the Medical Sciences, 1959, 237, 596.

${ }^{13}$ Matthews, H., Medicine (London), 1972, 4, 273.

14 Webster, L. T., and Gabuzda, G. J., Archiv os of Internal Medicine, 1959, $103,15$.

15 Zetterström, R., and Ernster, L., Nature, 1955, 178, 1335.

16 Palmer, R. H., Archives of Internal Medicine, 1972, 130, 606.

17 Aoyagi, T., and Lowenstein, L. M., fournal of Laboratory and Clinical Medicine, 1968, 71, 686.

${ }^{18}$ Lascelles, P. T., in Experimental Biology and Medicine, ed. E. Polli, vol. 4, p. 104. Basle, Karger, 1971.

19 Fulop, M., Katz, S., and Lawrence, C. Archives of Internal Medicine,

20 Weiner, I. M., Glasser, J. E., and Lack, L. American fournal of Physiology, 1964, 207, 964.

21 Gipstein, R. M., and Boyle, J. D., New England fournal of Medicine, 1965, 272, 1116.

${ }^{22}$ Reuff, B., Menache, D., Sicot, C., and Benhamou, J.-P., Minnesota Medicine, 1971, 54, 91 .

23 Cattel, W. R., in Sixth Symposium on Advanced Medicine, ed. J. D. H. Slater, p. 191. London, Pitman Medical and Scientific, 1970.

24 Baldus, W. P., in Progress in Liver Disease, ed. H. Popper and F. Schaffner, vol. 4, p. 251 . New York, Grune and Stratton, 1973. 